\title{
16. A POLLEN ANALYSIS OF THE INDUS DEEP SEA FAN FROM SITE 720 CORES1
}

\author{
Yasuda Yoshinori, ${ }^{2}$ Nobuaki Niitsuma,${ }^{3}$ and Akira Hayashida ${ }^{4}$
}

\begin{abstract}
Pollen analytical studies of the ODP Site 720 cores revealed the wide development of the coniferous forest, which mainly composed by Pinus, Picea, Abies and Cedrus deodara, along the Indus river since the early Pleistocene.
\end{abstract}

\section{METHOD AND LITHOLOGY}

ODP Site 720 cores were recovered from the westernmost part of the middle Indus Deep Sea Fan $\left(10^{\circ} 07^{\prime} \mathrm{N}, 60^{\circ} 44^{\prime} \mathrm{E}\right.$, $4037 \mathrm{~m}$ in water depth (Fig. 1). The total length of the ODP Site 720 core was $414.3 \mathrm{~m}$. The stratigraphic sequence of Site 720 core has been subdivided into two lithologic units, as shown in Figure 2. Lithologic unit I (between 0 and $17.22 \mathrm{~m}$ ) is composed of gray nannofossil ooze and foraminifer. Lithologic Unit II (between 17.22 and $414.3 \mathrm{~m}$ ) is dominated by interbedded silts and sands. Paleomagnetism and nannofossils indicate that this $414.3 \mathrm{~m}$ core spans about 1.5 Ma. Brunhes normal epoch (ca. $0.73 \mathrm{Ma}$ ) is between Cores $6 \mathrm{X}-\mathrm{CC}$ and $5 \mathrm{X}-\mathrm{CC}$. The first occurrence of Emiliania huxleyi at $0.19 \mathrm{Ma}$ is located between Samples 1H-3-CC and 1H-5-CC (Fig. 2).

Palynomorphs were separated from the sediment matrix by the heavy liquid flotation method modified from Faegri and Iversen (1964). The processing sequence is as follows: $\mathrm{HCl}$ $(10 \%)$ treatment, wash (in distilled water), $\mathrm{KOH}(10 \%)$ treatment, wash, float (zinc chloride heavy liquid flotation; specific gravity 2.1$), \mathrm{HCl}(1 \%)$ treatment, wash, dehydration (acetic acid), acetolysis (boiled for $3 \mathrm{~min}$ in water basin in a solution of 1 part concentrated sulfuric acid and 9 parts acetic anhydride), dehydration, wash, mount.

The material was examined at $400 \times$ magnification and, when necessary, oil immersion was used. Generally more than 200 pollen grains were identified in each sample.

As well as observation using light microscope, the samples were also studied using SEM. Residual materials were fixed by Carnoy's fluid ( 3 parts alcohol and 1 part acetic acid) for $1 \mathrm{hr}$. The fixed material was washed by alcohol and then fixed by isoamylacetate for $30 \mathrm{~min}$. A drop of the material was put on a brass stage and allowed to dry naturally, then coated by Au-Pd target for $2 \mathrm{~min}$ in the Ion Sputter Fine Coat.

\footnotetext{
${ }^{1}$ Prell, W. L., Niitsuma, N., et al., 1991. Proc. ODP Sci. Results, 117: College Station, TX (Ocean Drilling Program).

2 International Research Center for Japanese Studies, Kyoto, Japan.

3 Department of Earth Science, Shizuoka University, Shizuoka, Japan.

${ }^{4}$ Faculty of Engineering, Doshisha University, Kyoto, Japan.
}

The pollen diagram (Fig. 2) was constructed in terms of percentages of the total pollen. Representative fossil pollen are shown in Plates 1-5.

\section{RESULTS OF POLLEN ANALYSIS}

Pinus, Cedrus deodara, Abies, Picea, Alnus, Ephedra, Euphorbiaceae, Thalictrum, Chenopodiaceae, Artemisia, Gramineae, and Typha show high concentration. Although the frequencies are low, Acanthaceae, Altingia, Myrica, Myrtaceae, and Barringtonia appear.

\section{DISCUSSION}

Picea and Abies presently grow in the Himalayas at an altitude more than $2100 \mathrm{~m}$, and Cedrus deodara presently grows in the foot of Himalayas more than $1900 \mathrm{~m}$ where mean annual precipitation is less than $1200 \mathrm{~mm}$. According to the present ecological distribution of these trees, it is supposed that the pollen of Picea, Abies, Pinus, and Cedrus deodara were transported from the foot of the Himalayas by the northeast monsoon and Indus river. High concentration of these coniferous pollen indicate the wide distribution of coniferous forest which composed by Pinus, Picea, Abies, and Cedrus deodara along the Indus river since the early Pleistocene.

High values of Chenopodiaceae, Artemisia, and Ephedra which presently grow in the dry land suggest the development of dry climate along the coast of Indus Deep Sea Fan since the early Pleistocene.

There are several fluctuations of Gymnospermae which is composed of Picea, Abies, Pinus, Cedrus deodara, Tsuga, and Podocarpus, however, we cannot signify the meaning of these fluctuations, because of the poor core recovery.

\section{REFERENCES}

Faegri, K., and Iversen, J., 1964. Textbook of Pollen Analysis: New York (Hafner Press).

Shipboard Scientific Party, 1989. Site 720. In Prell, W. L., Niitsuma, N., et al., Proc. ODP, Init. Repts., 117: College Station, TX (Ocean Drilling Program), 157-195.

Date of initial receipt: 26 September 1989

Date of acceptance: 25 July 1990

Ms 117B-185 
Y. YOSHINORI, N. NIITSUMA, A. HAYASHIDA

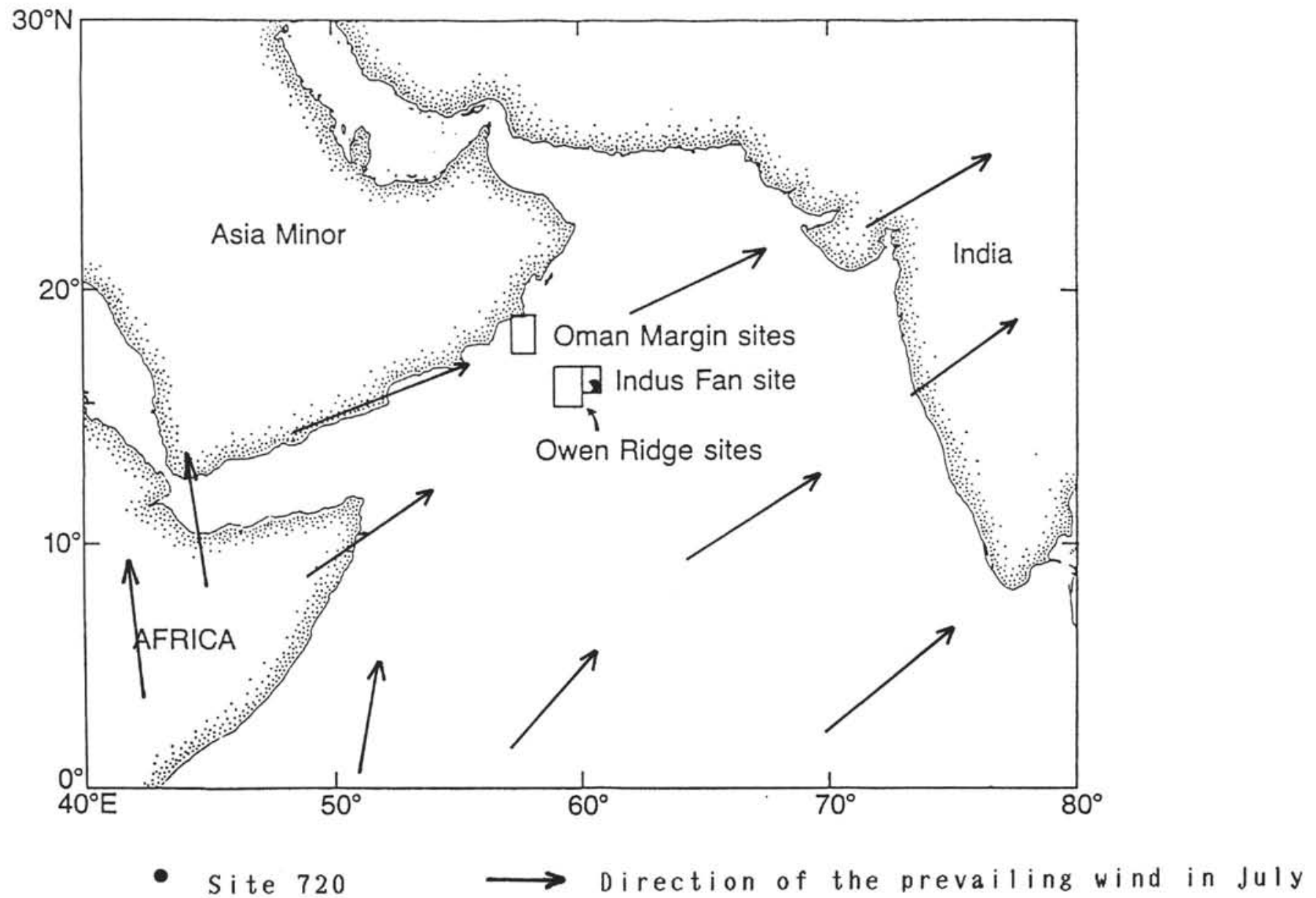

Figure 1. Location of ODP Site 720 (map after Shipboard Scientific Party, 1989). 


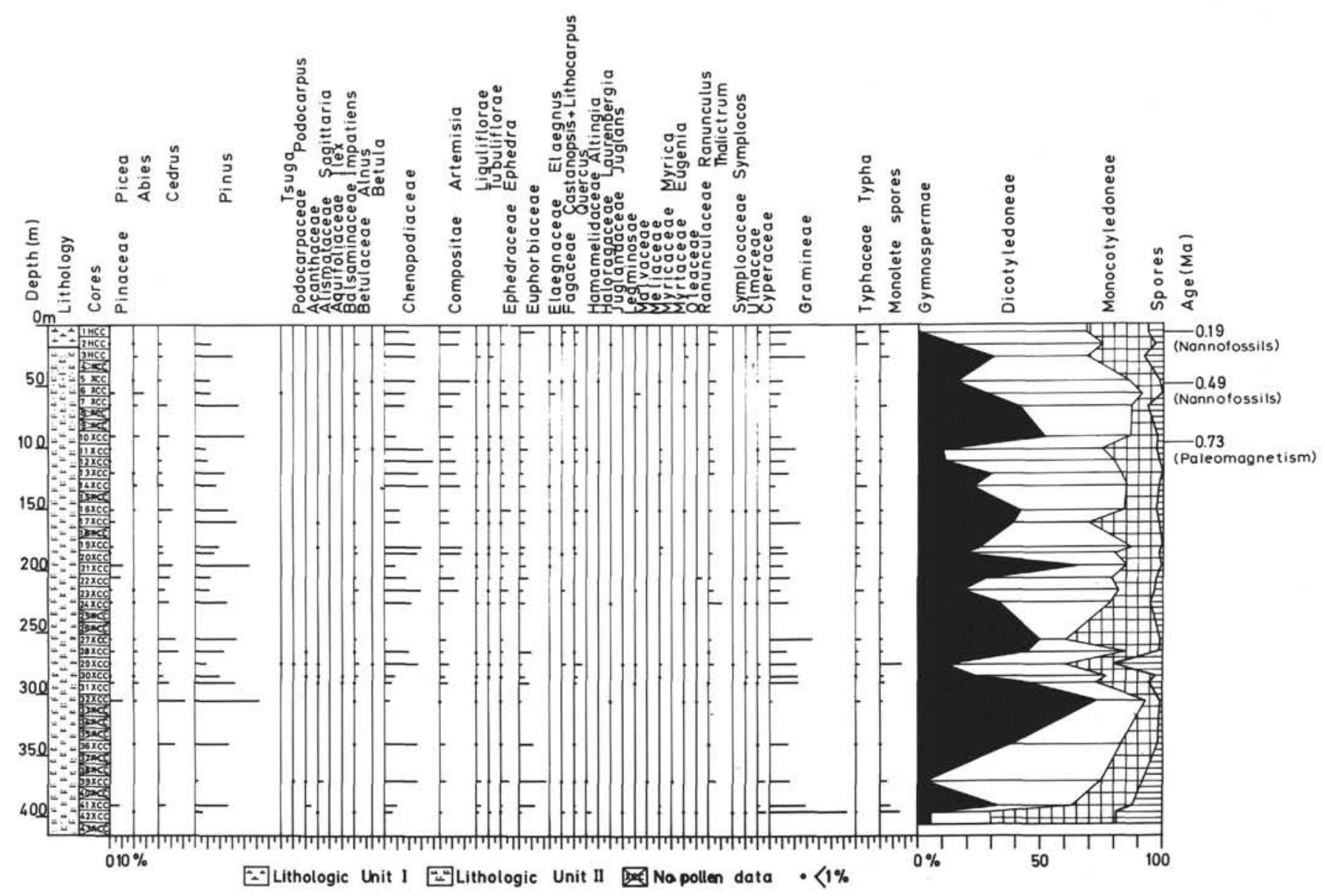

Figure 2. Pollen diagram of ODP Site 720. 


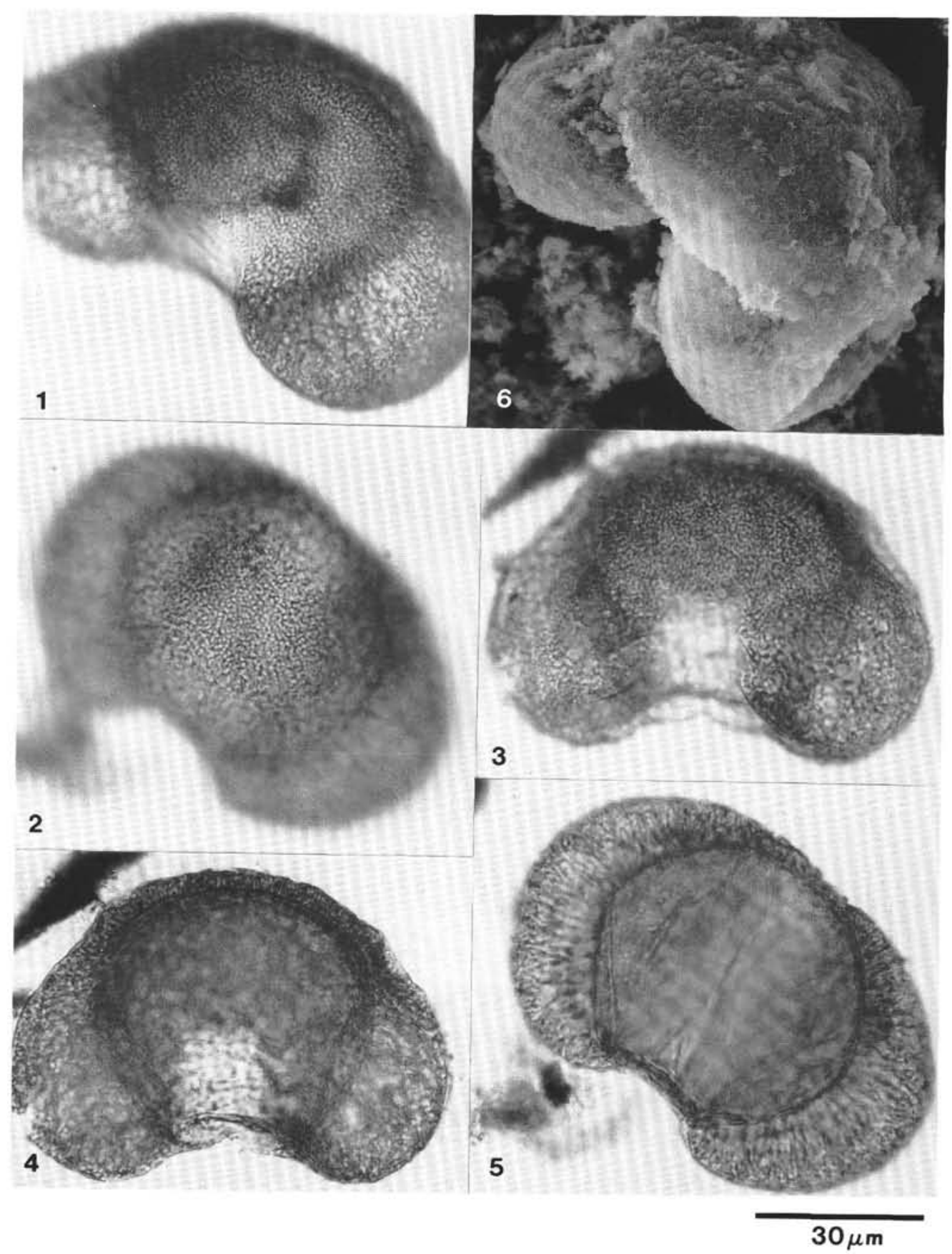

Plate 1. Fossil pollen from ODP Site 720 cores. 1-3. Cedrus deodara (LM high focus). 4-5. C. deodara (LM low focus), 6. C. deodara (SEM). 

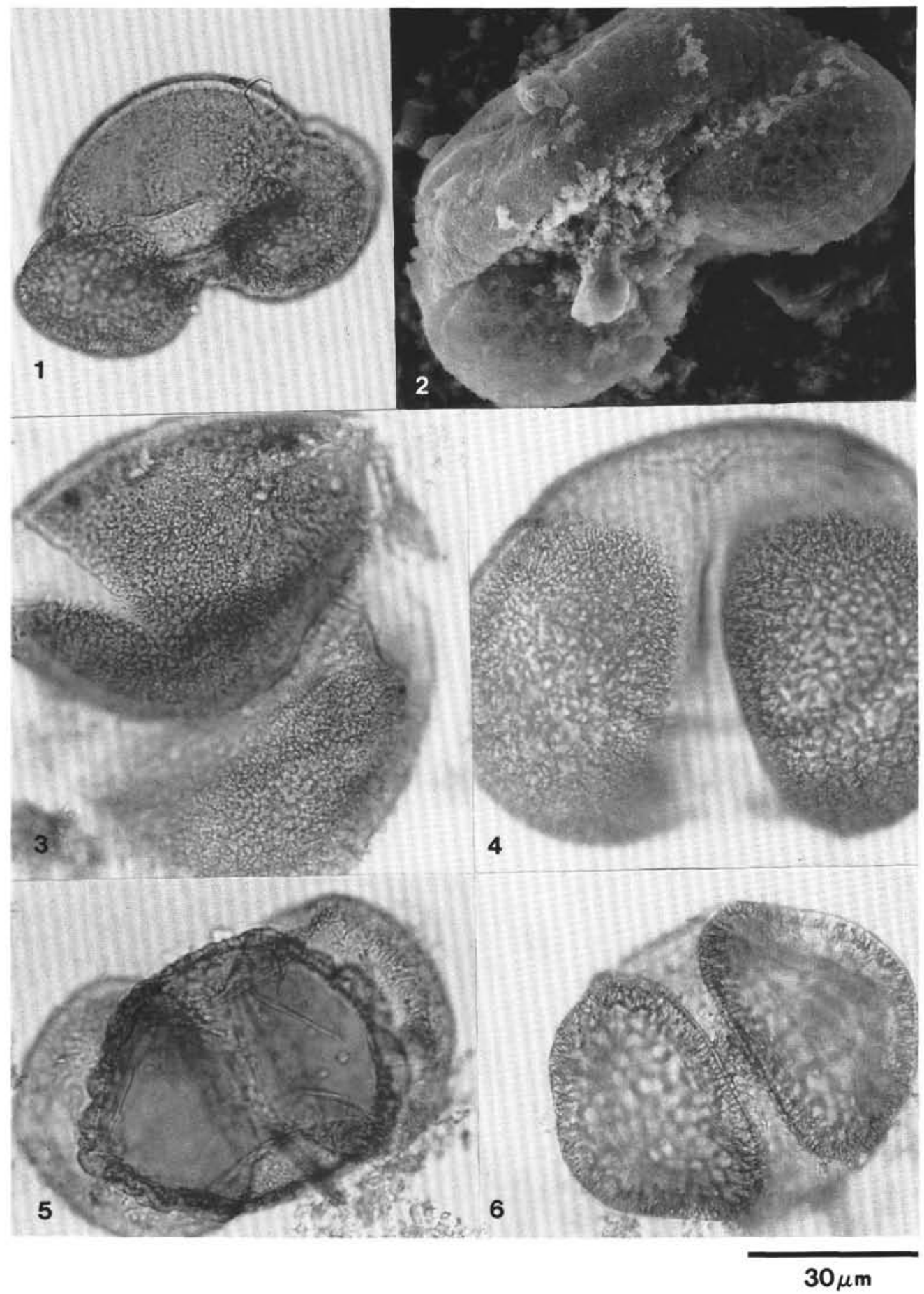

Plate 2. Fossil pollen from ODP Site 720 cores. 1. Pinus (LM). 2. Abies (SEM). 3-4. Picea (LM). 5-6. Pinus (LM). 


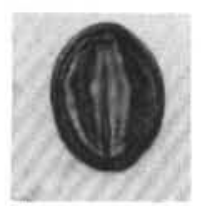

1
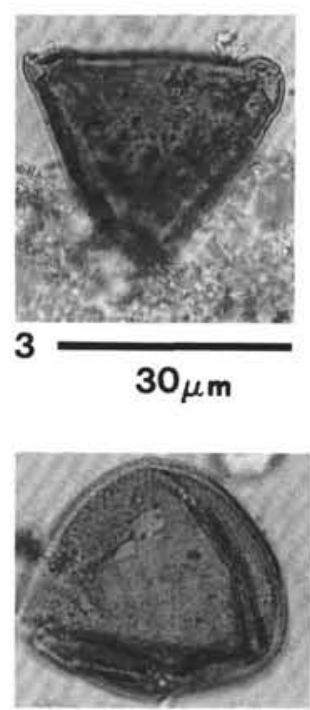

6

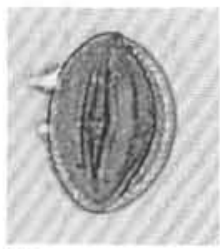

10

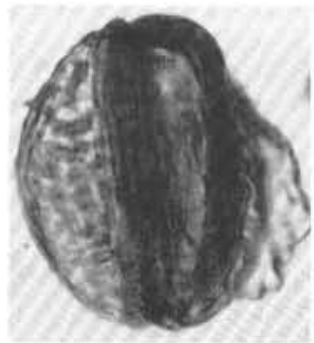

15

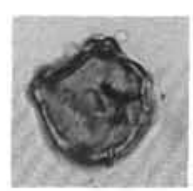

2

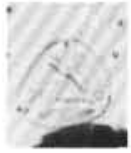

4

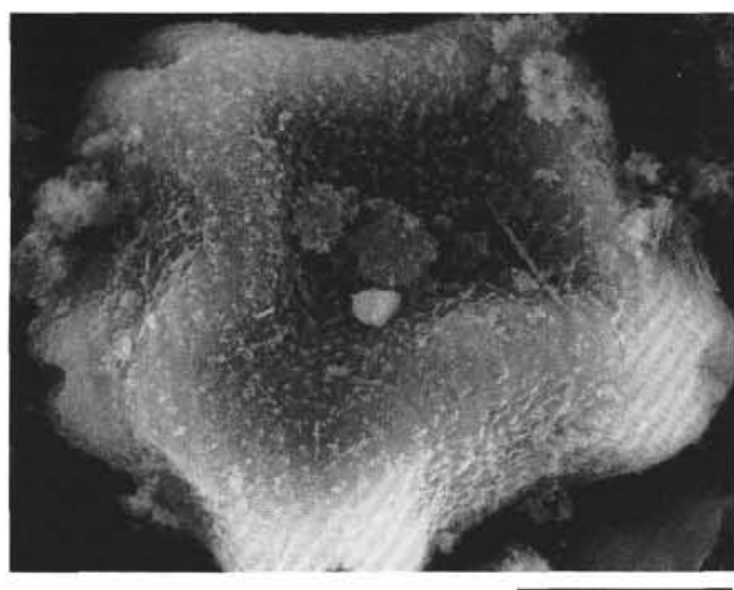

5

$5 \mu \mathrm{m}$

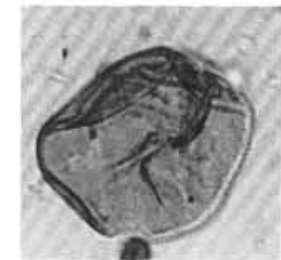

7

$30 \mu \mathrm{m}$

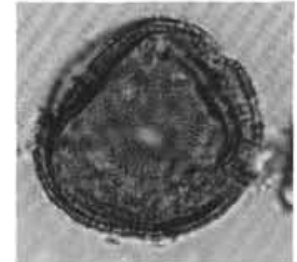

8

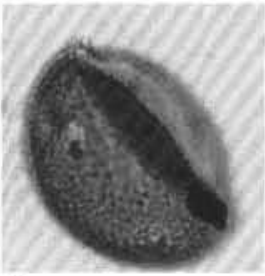

9

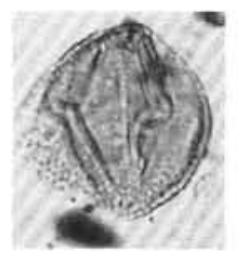

11

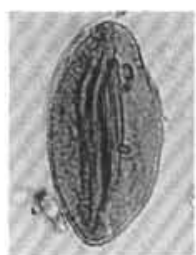

12

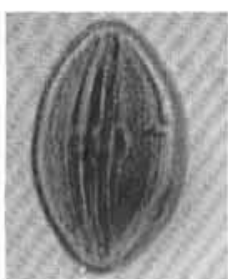

13

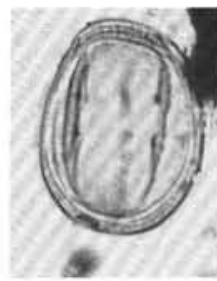

14

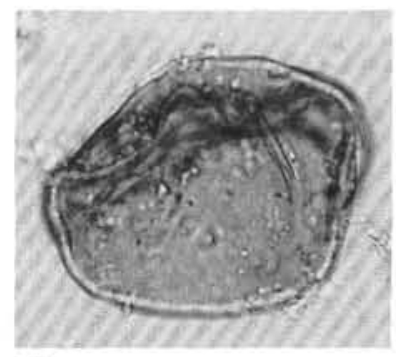

16

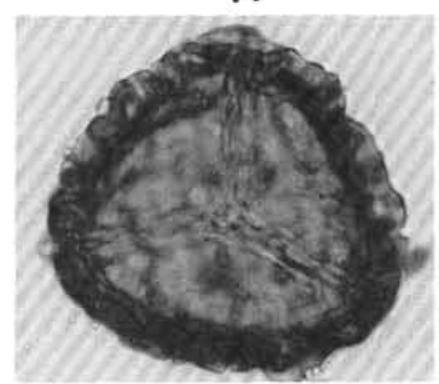

17

\section{$30 \mu \mathrm{m}$}

Plate 3. Fossil pollen and spore from ODP Site 720 cores. 1. Quercus (LM). 2. Alnus (LM). 3. Elaegnus (LM). 4. Myrtaceae (LM). 5. Alnus (SEM). 6-9. Altingia (LM). 10-13. Euphorbiaceae (LM). 14. Polygonum (LM). 15. Barringtonia (LM). 16. Juncaceae (LM). 17. Trilete spore (LM). 


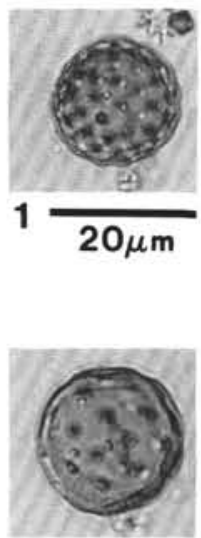

3

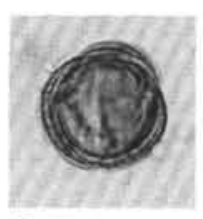

$6 \overline{20 \mu m} 7$

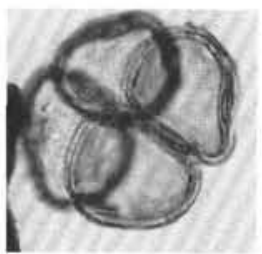

11

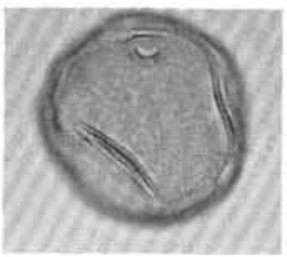

15

7

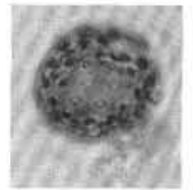

2

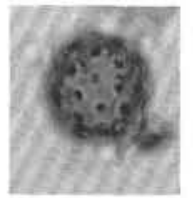

4

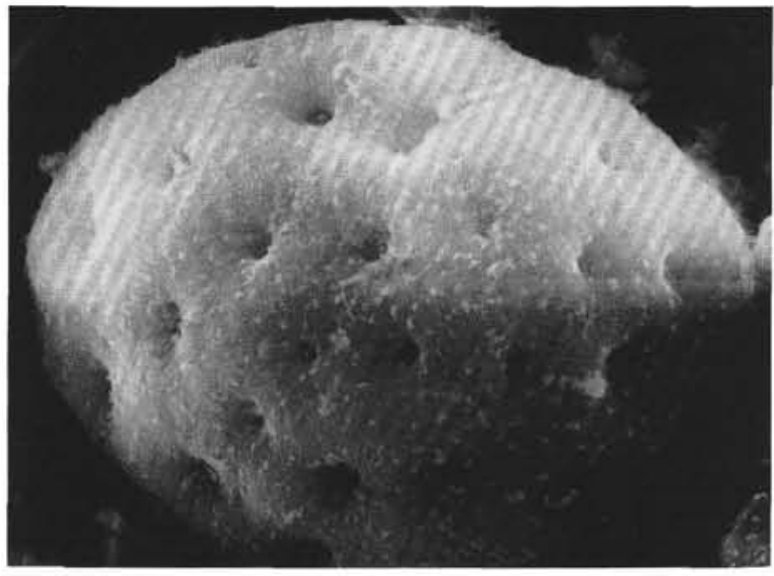

5

$5 \mu \mathrm{m}$
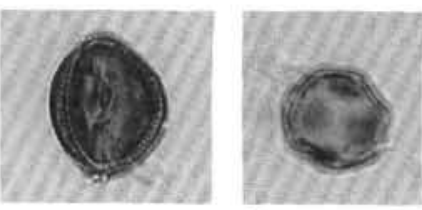

8

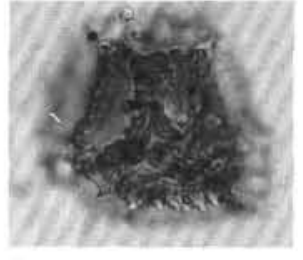

9

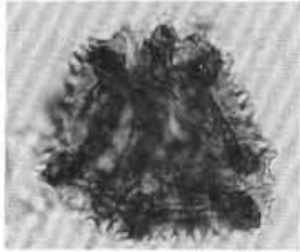

10

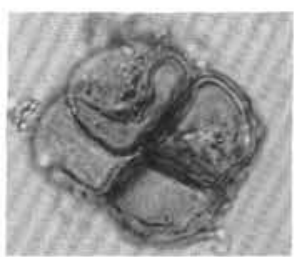

13

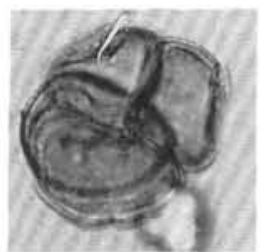

14
12

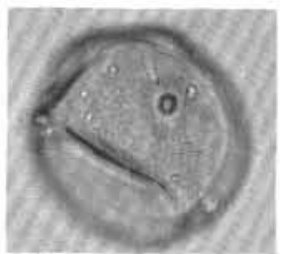

16

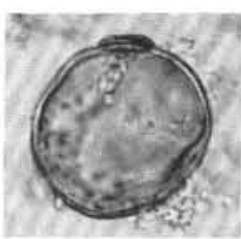

17

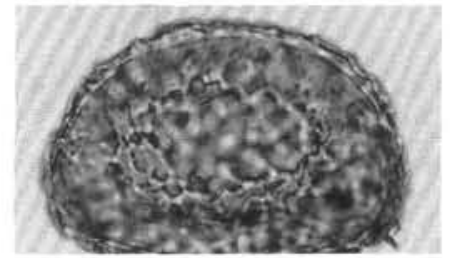

18

Plate 4. Fossil pollen and spore from ODP Site 720 cores. 1-4. Chenopodiaceae (LM). 5. Chenopodiaceae (SEM). 6-7. Artemisia (LM). 8. Thalictrum (LM). 9-10. Liguliflorae (LM). 11-14. Typha (LM). 15-17. Gramineae (LM). 18. Monolete spore (LM). 

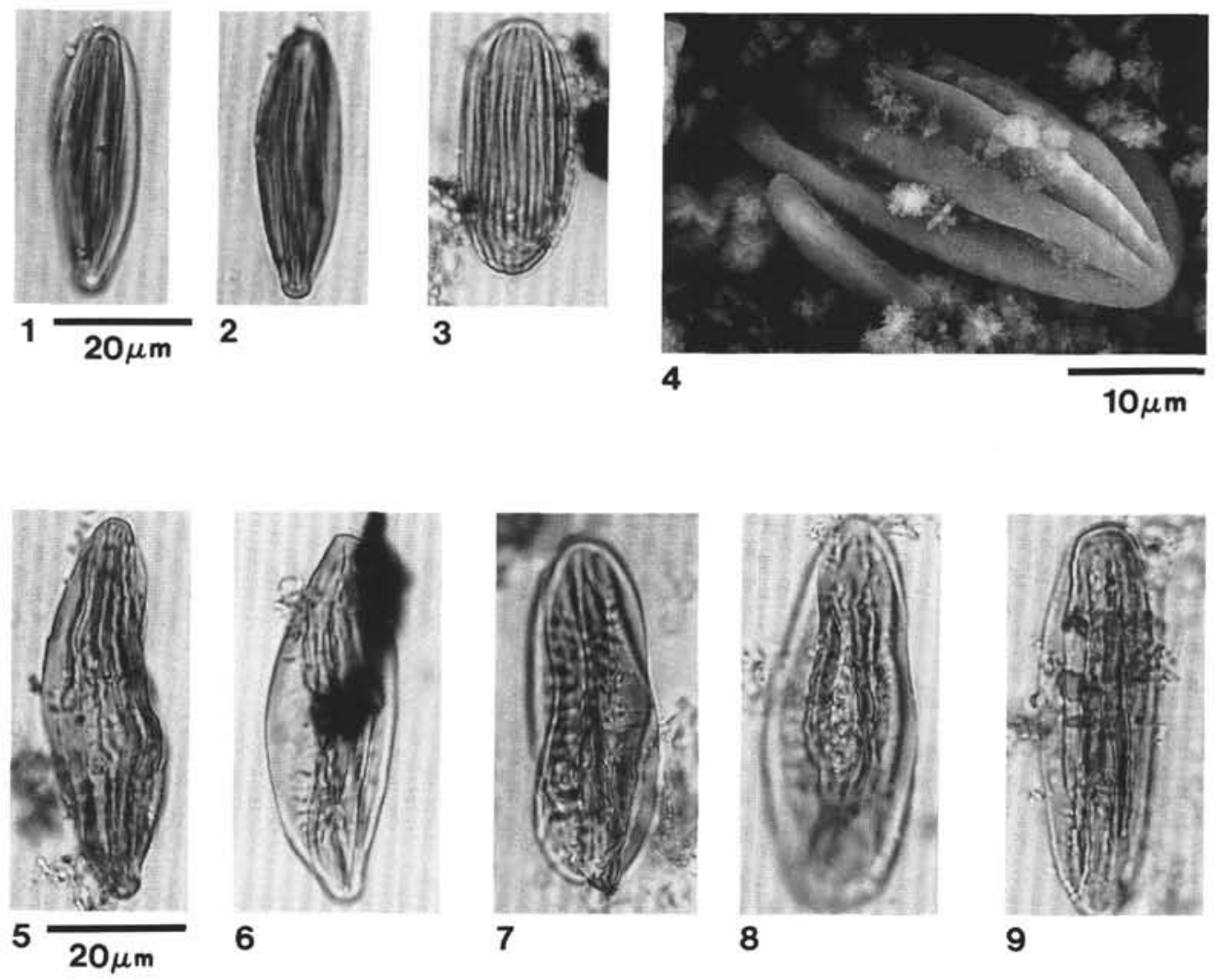

6

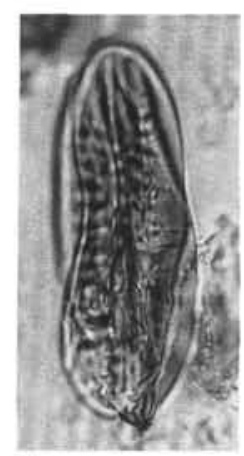

7

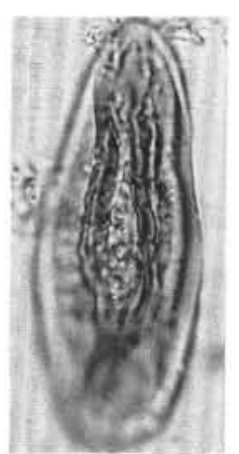

8

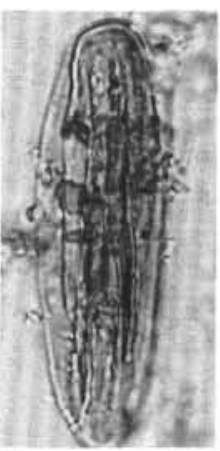

9

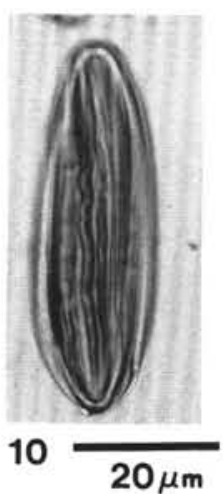

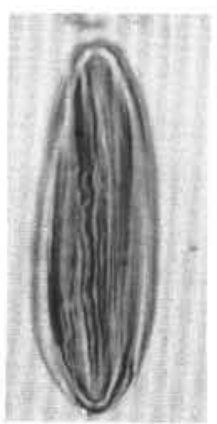

11

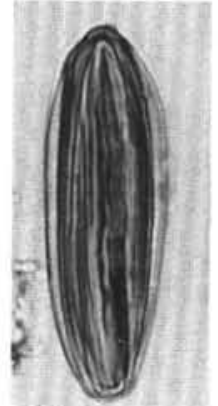

12

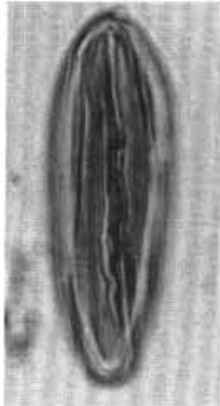

13

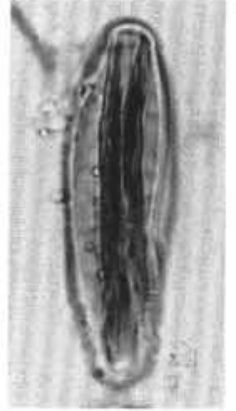

14

Plate 5. Fossil pollen from ODP Site 720 cores. 1-3. Ephedra (LM). 4. Ephedra (SEM). 5-14. Ephedra (LM). 